\title{
Coinfection of the Intestinal Tract with Aeromonas hydrophila, Clostridium difficile and Rotavirus - a Case Report
}

\author{
Petar Vasilev ${ }^{1,2}$, Mariya Ivanovska ${ }^{3,4,5}$, Gergana Lengerova ${ }^{3,4,5}$, Atanaska Petrova ${ }^{3,4,5}$, Eli Hristozova ${ }^{3,4}$, \\ Marianna Murdjeva ${ }^{3,4,5}$, Mariyana Stoycheva ${ }^{1,2}$ \\ ${ }^{1}$ Department of Infectious Diseases, Parasitology and Tropical Medicine, Medical University of Plovdiv, Plovdiv, Bulgaria \\ ${ }^{2}$ Clinic of Infectious Diseases and Parasitology, St George University Hospital, Plovdiv, Bulgaria \\ ${ }^{3}$ Department of Microbiology and Immunology, Faculty of Pharmacy, Medical University of Plovdiv, Plovdiv, Bulgaria \\ ${ }^{4}$ Laboratory of Microbiology, St George University Hospital, Plovdiv, Bulgaria \\ ${ }^{5}$ Research Institute, Medical University of Plovdiv, Plovdiv, Bulgaria
}

Corresponding author: Petar Vasilev, Department of Infectious Diseases, Parasitology and Tropical Medicine, Medical University of Plovdiv, 15A Vassil Aprilov Blvd., 4002 Plovdiv, Bulgaria; E-mail: pvasilev1985@gmail.com; Tel.: +359 898997091

Received: 16 June 2020 Accepted: 19 Feb 2021 Published: 31 Aug 2021

Citation: Vasilev P, Ivanovska M, Lengerova G, Petrova A, Hristozova E, Murdjeva M, Stoycheva M. Coinfection of the intestinal tract with Aeromonas hydrophila, Clostridium difficile and Rotavirus - a case report. Folia Med (Plovdiv) 2021;63(4):576-81. doi: 10.3897/ folmed.63.e55496.

\begin{abstract}
Most cases of acute diarrhea in adults are of infectious etiology, likely viral and self-limited. Among those with severe diarrhea, however, bacterial causes are responsible for most cases.

Apart from the standard stool cultures, to increase the positive yield a novel multiplex molecular test can be performed simultaneously. The authors present a patient with recurrent diarrhea and detection of Aeromonas hydrophila by culturing and Rotavirus and Clostridioides difficile by multiplex molecular test. They discuss and justify which is the most likely actionable pathogen. Good communication between the physicians and interpretation on the multiple positive results in the context of clinical picture and the test employed were important for a better management and favourable outcome of the patient.
\end{abstract}

\section{Keywords}

Aeromonas hydrophila, Clostridium difficile, multiplex PCR

\section{INTRODUCTION}

Diarrheal disease is one of the top ten leading causes of death worldwide and is a particular concern for children younger than five years old in resource-limited settings. ${ }^{1}$ Among adults in resource-rich settings, diarrhea is often a "nuisance disease" in the healthy individual. Most cases of acute diarrhea are of infectious etiology, commonly viral and self-limited. Noroviruses have surpassed rotaviruses as the most common pathogens in regions where rotavirus vaccine has become routine. Among those with severe diarrhea, however, bacterial causes are responsible for most cases. ${ }^{2}$ Nosocomial Clostridioides (formerly Clostridium) difficile (Cl. difficile) infection is one of the most common hospital-acquired (nosocomial) infections and is an increasingly frequent cause of morbidity and mortality among older adult hospitalized patient. ${ }^{3}$

Copyright by authors. This is an open access article distributed under the terms of the Creative Commons Attribution License (CC-BY 4.0), 
Stool cultures have been the standard diagnostic tool for determining the microbial etiology of suspected bacterial infectious diarrhea although time consuming, costly, and with low positive yield. Rapid and accurate diagnostic tools are needed for appropriate management of infectious diarrhea. Commercially available multiplex polymerase reaction (PCR) may improve patient care by allowing clinicians to choose the appropriate antimicrobials or to avoid them if not indicated. ${ }^{4}$ However, their potential for yielding results of unclear medical significance, including false positives and multiple positives per sample has been extensively documented. ${ }^{5}$ The authors aimed to evaluate a patient with recurrent diarrhea and possible coinfection with enteric pathogens. Methods, characteristic of clinical and epidemiological research, were applied. Methods, implemented in the establishment of the etiological diagnosis, include standard stool culturing (Salmonella spp., Shigella spp., Campylobacter spp.), automatic identification techniques and antibiotic susceptibility testing; for $\mathrm{Cl}$. difficile Toxins $\mathrm{A}$ and $\mathrm{B}$ by enzyme-linked immunosorbent assay (ELISA) (Savyon Diagnostics) and stool sample through multiplex polymerase chain reaction (mPCR) FilmArray (Biofire $^{\circledast}$ ) (a gastrointestinal panel for 22 pathogens causing diarrhea). Detection of Aeromonas: Bacterial pure culture was detected, with lactose-negative colonies lacking dark center, normally associated with the production of hydrogen sulfide. Microscopy revealed gram-negative rods. After positive oxidase test the diagnostic thinking shifted to Pseudomonas, Aeromonas or NAG Vibrio as possible causative agents of infectious diarrhea. Further cultivation on Kligler-iron agar proved glucose fermentation, lack of lactose fermentation and lack of $\mathrm{H} 2 \mathrm{~S}$ production. The indole test was positive and urease production negative. The final identification was performed by VITEK-2 automated system (BioMerieux, France), which proved the microorganism to be Aeromonas hydrophila (97\%). The antimicrobial sensitivity was determined by disk-diffusion test (DDT) of Bauer-Cirby on Mueller-Hinton agar and the minimal inhibitory concentrations (MIC) were evaluated by VITEK-2. The interpretation was made with regard to the criteria of EUCAST 2019. The isolate was susceptible to all antibiotics recommended by the standard (cefepime, ceftazidime, ciprofloxacin, levofloxacin, trimethoprim/ sulfamethoxazole, aztreonam). Serum and fecal cytokine concentrations on IL-1b (15.6-500 pg/ml), IL-6 (6.25200 pg/ml), IL-8 (62.5-2000 pg/ml), IL-10 (12.5-400 pg/ $\mathrm{ml})$, TNF-l (25-800 pg/ml) were determined via ELISA with Diaclone SAS, France kits and reported using spectrophotometric techniques (TECAN sunrise reader, Tecan Trading AG, Switzerland). The research was carried out in the Department of Microbiology and Immunology and the Research Institute of the Medical University of Plovdiv. The present scientific report has been realized thanks to the scientific research project DPDP - 02/2018 of the Medical University of Plovdiv.

\section{CASE REPORT}

A previously healthy 41-year-old woman presented to her general practitioner with a 3-day history of fever and cough. She was prescribed amoxicillin/clavulanic acid for presumptive bronchitis. On the second day diarrhea and abdominal pain developed. She was admitted to St George University Hospital, Department of Infectious Diseases on January 4, 2020 for further evaluation and treatment. The woman had no concomitant diseases other than recent oligomenorrhea for which she was followed-up by an obstetrician-gynecologist. The patient had been taking seaweed food supplement for several months. The physical examination revealed normal vital sings and temperature $37.8^{\circ} \mathrm{C}$. She appeared comfortable. Apart from mild tenderness on palpation in the epigastrium region, the remainder of physical examination was normal. Complete blood count was notable for mild leukocytosis. Stool sample culture did not give growth. Result for $C l$. difficile toxins $A / B$ was negative. She was given intravenous fluids, ceftriaxone 2.0 i.v. daily and antispasmodics. Her condition quickly improved, diarrhea resolved and she was discharged with a recommendation to discontinue the intake of food supplement.

Five days later her condition deteriorated, temperature, abdominal pain and watery diarrhea recurred. Blood investigations revealed neutrophilia (WBC $24.93 \mathrm{G} / \mathrm{l}$ ). She was referred to an obstetrician-gynecologist who ruled out a possible gynecological disease. The patient presented to the Emergency Department of St George University Hospital in Plovdiv on January 15, 2020. The chest radiograph revealed enhanced interstitial lung pattern; the abdominal ultrasound was without abnormities. She was consulted by a surgeon, an urologist, a nephrologist, and an infectious diseases specialist. A mutual decision was made about a possible recurrence of the previous disease, or newly acquired intestinal infection, which required hospital admission and the patient was admitted again to the Department of Infectious Diseases. Upon admission, the woman was with normal vital signs; her temperature was $38.5^{\circ} \mathrm{C}$ and she was moderately dehydrated. The physical examination revealed abdominal tenderness and increased intestinal peristalsis. Her initial blood investigations are presented in Table 1. The complicated course of the disease prompted the treating physicians to expand their clinical reasoning - in addition to a repeat stool culture $M P C T$ in feces was ordered as well. Patient's serum and fecal concentrations of cytokines (IL-10, IL-8, IL-6, TNF- $\alpha$, and IL-1b) were also studied. Specimen for blood culture was not taken. Treatment with ciprofloxacin $2 \times 0.4$ i.v., vancomycin $4 \times 125$ $m g$ per os, intravenous and oral rehydration solution were applied. On the third day, the stool culture grew Aeromonas hydrophila (A. hydrophila) and MPCR detected $\mathrm{Cl}$. difficile and rotavirus (Table 2). Elevated serum concentrations of IL-6 $(240.42 \mathrm{pg} / \mathrm{ml})$ and fecal concentrations of IL-1 $(1363.32 \mathrm{pg} / \mathrm{ml})$ were found.

In the next days, the diarrhea was overcome, as was the abdominal pain. After 5 days the patient improved and was 
discharged with prescription for ciprofloxacin $2 \times 0.5$ orally for five days.

A follow-up one year later by telephone interview found that she was doing well trying to conceive through in vitro fertilization.

\section{DISCUSSION}

In this study we presented a patient with recurrent diarrhea and evidence of 3 enteric pathogens: A. hydrophila, $\mathrm{Cl}$. difficile and rotavirus.

It is not easy to decide which of the verified pathogens has a leading role in the disease.

Rotavirus gastroenteritis has a pronounced seasonality, occurring mainly during the cold months as epidemics or nosocomial infections in young children. Rotavirus antigen may be identified by several means, ELISA assay being the most common. Only the first encounter with rotavirus can lead to more severe diarrhea, and subsequent infections are mild or unapparent. Rotavirus asymptomatic carriage occurs in about $3 \%$ of adults. However, this patient we present had recurrent diarrhea and abdominal pain. ${ }^{1,2}$ The discrepancy between the severe clinical presentation and molecular result made rotavirus unlikely reason.

It is quite difficult to evaluate the significance of toxigenic $\mathrm{Cl}$. difficile. In our case it has not been detected by ELISA, but by multiplex PCR. ELISA for $\mathrm{Cl}$. difficile toxin $\mathrm{A} / \mathrm{B}$ is the most commonly used diagnostic test. ${ }^{6}$ ELISA is not a reliable method when used alone, due to the wide range of specificity (from $75 \%$ to $>99 \%{ }^{7}$ ) and sensitivity (from $32 \%$ to $73 \%^{8}$ ) that depend on the reference standard used $^{9}$. It is preferable to use a method that detects toxin $\mathrm{A}$ and $\mathrm{B}$, as strains that only produce toxin $\mathrm{B}$ and not toxin $\mathrm{A}$ are reported. ${ }^{10}$

The Infectious Diseases Society of America, the Society for Healthcare Epidemiology of America and the European Society of Clinical Microbiology and Infectious Diseases

Table 1. Initial blood results in the patient

\begin{tabular}{|c|c|c|c|c|}
\hline Date & 15.1 .2020 & 16.1 .2020 & & \\
\hline Component & & & Reference range & Units \\
\hline Hemoglobin (HGB) & 135 & 120 & $120-160$ & $\mathrm{~g} / \mathrm{l}$ \\
\hline Red blood cells (RBC) & 4.76 & 4.33 & $3.9-5.3$ & $\mathrm{~T} / \mathrm{l}$ \\
\hline Hematocrit (HCT) & 0.407 & 0.358 & $0.36-0.47$ & $\%$ \\
\hline White blood cells (WBC) & 29.07 & 16.5 & $3.5-10.5$ & $\mathrm{G} / \mathrm{l}$ \\
\hline Platelets (PLT) & 248 & 200 & $140-400$ & $\mathrm{G} / \mathrm{l}$ \\
\hline Erythrocyte sedimentation rate (ESR) & - & 33 & $2-25$ & $\mathrm{~mm} / \mathrm{h}$ \\
\hline Neutrophils (Neu) & - & 90 & $42-70$ & $\%$ \\
\hline Lymphocytes (Ly) & - & 7 & $22-48$ & $\%$ \\
\hline Monocytes (Mo) & - & 2 & $6-12$ & $\%$ \\
\hline Eosinophils (Eo) & - & 0.5 & $0-6$ & $\%$ \\
\hline Basophils (Ba) & - & 0.5 & $0-2$ & $\%$ \\
\hline $\mathrm{C}$ reactive protein (CRP) & & 188 & $0-10$ & $\mathrm{mg} / \mathrm{l}$ \\
\hline
\end{tabular}

Table 2. FilmArray Gastrointestinal Panel Multiplex PCR (Biofire ${ }^{\circledast}$ ) results in the patient

\begin{tabular}{ll}
\hline BACTERIA & PARASITES \\
\hline Campylobacter & Cryptosporidium \\
Clostridium difficile toxins $\boldsymbol{A} / \boldsymbol{B} \checkmark$ Detected & Cyclospora cayetanensis \\
Plesiomonas shigelloides & Entamoeba histolytica \\
Salmonella & Giardia lamblia \\
Vibrio & \\
Vibrio cholerae & VIRUSES \\
Yersinia enterocolitica & Adenovirus F 40/41 \\
Enteroaggregative E. coli (EAEC) & Astrovirus \\
Enteropathogenic E. coli (EPEC) & Norovirus GI/GII \\
Enterotoxicogenic E. coli (ETEC) & Rotavirus $\boldsymbol{A} \checkmark$ Detected \\
Shiga-toxin producing E. coli (STEC) & Sapovirus \\
E. coli O 157 & \\
Shigella/Enteroinvasive E. coli (EIEC) & P.S. Speed of the test -70 minutes. \\
\hline
\end{tabular}


guidelines recommend $\mathrm{Cl}$. difficile toxin detection and nucleic acid amplification test (NAAT) as the most effective and sensitive diagnostic tests. To optimize $\mathrm{Cl}$. difficile diagnosis two-step algorithms are currently recommended: e.g. glutamate dehydrogenase test (GDH) test plus toxin detection (ELISA); GDH test plus evidence of toxin arbitrated by NAAT; or NAAT plus toxin detection test. ${ }^{11}$ No single test can be recommended as a stand-alone test for diagnosing Cl. difficile. ${ }^{1}$

Although re-examination of feces in patients with negative tests for $\mathrm{Cl}$. difficile is a common procedure, there is little evidence to support this practice. This is due to the low sensitivity of ELISA and studies show that $10 \%$ of patients who initially test negative for $\mathrm{Cl}$. difficile toxin will test positive in the second testing. ${ }^{12-16}$

The inability to verify toxigenic $\mathrm{Cl}$. difficile by other means in the case presented made us doubt this diagnosis. Moreover, previous antibiotic use may shift the likelihood that the detected $\mathrm{Cl}$. difficile are more than colonizers.

Low concentrations of IL- 6 in feces can be regarded as another finding, which is difficult to be explained. We would rather expect elevated values of the aforementioned as a result, additionally supported by data from other authors in various intestinal infections with diarrheal syndrome. Moreover, according to other studies, the level of IL- 6 in feces correlates with the severity of the disease development. ${ }^{17,18}$

Culturing of $A$. hydrophila from the stool of the patient is the only direct evidence of the presence of an enteric pathogen. The genus Aeromonas consists of gram-negative rods widely distributed in freshwater, estuarine, and marine environments. The genus Aeromonas was re-categorized from the family Vibrionaceae to the family Aeromonadaceae in the mid-1980s. ${ }^{19}$ About $95.4 \%$ of the strains associated with humans correspond to 4 species: A. caviae, A. dhakensis, A. veronii, and A. hydrophila. Aeromonas species are considered emerging pathogens that cause a wide spectrum of diseases in humans, mainly diarrhea, wound infection and bacteriemia. ${ }^{20}$

Aeromonas organisms grow in routine culture but are frequently overlooked unless their isolation is specified; thus, when Aeromonas is suspected, the laboratory must be advised to look for this organism. ${ }^{21}$ Clinical studies have demonstrated differences in antimicrobial susceptibility between species, highlighting the importance of both species identification and susceptibility testing for all isolates, particularly in the setting of serious infection. Most cases of Aeromonas-associated diarrhea are self-limited and can be managed with supportive therapy, including oral and intravenous rehydration. Based on anecdotal data, antibiotics may be of value in patients with severe diarrhea and/or a history of immunosuppression. ${ }^{22}$ Antibiotic therapy is always indicated in the setting of wound infection and bacteremia. Empiric therapy of suspected Aeromonas infections (severe diarrhea, wound infections, bacteremia) with a fluoroquinolone, third generation cephalosporin, or trimethoprim/sul- famethoxazole is recommended pending species identification and susceptibility testing. ${ }^{23}$

While initially missed to be cultured, A. hydrophila was detected during the second admission of our patient. Despite this unexpected finding, her recent exposure to seaweed food supplement might be the explanation. Appropriate therapy led to her uneventful recovery.

In summary, we were able to detect simultaneously A. hydrophila by culturing the stool sample and rotavirus and $\mathrm{Cl}$. difficile by applying mPCR. Mixed positive finding per sample by mPCR is not uncommon. It is a result of its reliance on amplification of genetic loci which may persist in the gut during asymptomatic carriage or be transferred horizontally between enteric bacteria. ${ }^{24,25}$ Therefore, all identified bacteria in the stool should be confirmed in conventional culture methods. Clinical judgment combined with mPCR and confirmatory stool cultures can provide an approach to infectious gastroenteritis that is both rapid and accurate. Finally, we considered that A. hydrophila played a major role as a possible pathogen in the clinical presentation of the patient described herein while positive MPCR results were accepted as non-contributing accidental findings.

\section{CONCLUSIONS}

In case of co-detected pathogens the clinician has to decide which is the more (or the most) actionable agent. Good communication between physicians and always interpretation of the results in the context of clinical finding are crucial for favourable outcome of the patient.

\section{REFERENCES}

1. Troeger C, Blacker BF, Khalil IA, et al. Estimates of the global, regional, and national morbidity, mortality, and aetiologies of diarrhoea in 195 countries: a systematic analysis for the Global Burden of Disease Study 2016. Lancet Infect Dis 2018; 18(11):121128.

2. Shane AL, Mody RK, Crump JA, et al. 2017 Infectious Diseases Society of America clinical practice guidelines for the diagnosis and management of infectious diarrhea. Clin Infect Dis 2017; 65(12):e4580.

3. Lessa FC, Mu Y, Bamberg WM, et al. Burden of Clostridium difficile infection in the United States. N Engl J Med 2015; 372:825-34.

4. Torres-Miranda D, Akselrod H, Karsner R, et al. Use of BioFire FilmArray gastrointestinal PCR panel associated with reductions in antibiotic use, time to optimal antibiotics, and length of stay. BMC Gastroenterol 2020; 20(1):246.

5. Binnicker MJ. Multiplex molecular panels for diagnosis of gastrointestinal infection: performance, result interpretation, and cost-effectiveness. J Clin Microbiol 2015; 53:3723.

6. Bartlett JG, Gerding DN. Clinical recognition and diagnosis of Clostridium difficile infection. Clin Infect Dis 2008; 46:12-8.

7. Vanpoucke H. Evaluation of six commercial assays for the rapid detection of Clostridium difficile toxin and/or antigen in stool specimens. Clin Microbiol Infect 2001; 7:55-64.

8. Barbut F. Comparison of three enzyme immunoassays, a cyto- 
toxicity assay, and toxigenic culture for diagnosis of Clostridium difficile-associated diarrhea. J Clin Microbiol 1993; 3:963-7.

9. Dubberke ER, Donskey CJ. Contemporary Diagnosis and Management of Clostridium difficile Infection. Newtown, Pennsylvania, USA: Handbooks in Health Care Co; 2011:62.

10. Johnson S. Fatal pseudomembranous colitis associated with a variant Clostridium difficile strain not detected by toxin A immunoassay. Ann Intern Med 2001; 135:434-8.

11. McDonald LC, Gerding DN, Johnson S, et al. Clinical practice guidelines for clostridium difficile infection in adults and children: 2017 update by the Infectious Diseases Society of America (IDSA) and Society for Healthcare Epidemiology of America (SHEA). Clin Infect Dis 2018; 987-94.

12. Cohen SH. SHEA-IDSA guideline: Clinical practice guidelines for Clostridium difficile infection in adults: 2010 update by the Society for Healthcare Epidemiology of America (SHEA) and the Infectious Diseases Society of America (IDSA). Infect Control Hosp Epidemiol 2010; 31:431-55.

13. Mohan SS, McDermott BP, Parchuri S. Lack of value of repeat stool testing for Clostridium difficile toxin. Am J Med 2006; 119:356-8.

14. Cardona DM, Rand KH. Evaluation of repeat Clostridium difficile enzyme immunoassay testing. J Clin Microbiol 2008; 46:3686-9.

15. Aichinger E, Schleck CD, Harmsen WS. Nonutility of repeat laboratory testing for detection of Clostridium difficile by use of PCR or enzyme immunoassay. J Clin Microbiol 2008; 46:3795-7.

16. El-Gammal A, Scotto V, Malik S. Evaluation of the clinical usefulness of Clostridium difficile toxin testing in hospitalized patients with diarrhea. Diagn Microbiol Infect Dis 2000; 36:169-73.
17. Stoycheva MS, Murdjeva MA. Correlation between serum levels of interleukin-1 $\beta$, interleukin-1RA, interleukin-6, interleukin-10, interleukin 12 , tumor necrosis factor- $\alpha$ and interferon- $\gamma$ with some clinical and laboratory parameters in patients with salmonellosis. Biotechnology \& Biotechnological Equipment. 2005; 19(1):143-6.

18. Stoycheva MS. Salmonellosis. Plovdiv, 2005:198.

19. Martin-Carnahan A, Joseph SW. Aeromonas. In: Brenner JD, Krieg NR, Staley JT, Garrity GM, editors. Bergey's Manual of Systematic Bacteriology. Vol 2. 2nd ed., New York: Williams and Wilkins; 2005.

20. Janda JM, Abbott SL. Evolving concepts regarding the genus Aeromonas: an expanding Panorama of species, disease presentations, and unanswered questions. Clin Infect Dis 1998; 27:332.

21. Carnahan AM, Behram S, Joseph SW. Aerokey II: a flexible key for identifying clinical Aeromonas species. J Clin Microbiol 1991; 29:2843.

22. Vila J, Marco F, Soler L, et al. In vitro antimicrobial susceptibility of clinical isolates of Aeromonas caviae, Aeromonas hydrophila and Aeromonas veronii biotype sobria. J Antimicrob Chemother 2002;49:701.

23. Overman TL, Janda JM. Antimicrobial susceptibility patterns of Aeromonas jandaei, A. schubertii, A. trota, and A. veronii biotype veronii. J Clin Microbiol 1999; 37:706.

24. Zhang H, Morrison S, Tang YW. Multiplex polymerase chain reaction tests for detection of pathogens associated with gastroenteritis. Clin Lab Med 2015; 35:461-86.

25. Lunghi G, Ardissino G, Girello A, et al. FilmArray GI panel performance for the diagnosis of acute gastroenteritis or hemorrhagic diarrhea. BMC Microbiol 2017; 17:111. 


\title{
Коинфекция кишечного тракта с Aeromonas hydrophila, Clostridium difficile и Rotavirus - отчет о клиническом случае
}

\author{
Петар Василев ${ }^{1,2}$, Мария Ивановска ${ }^{3,4,5}$, Гергана Ленгерова ${ }^{3,4,5}$, Атанаска Петрова ${ }^{3,4,5}$, \\ Ели Христозова ${ }^{3,4}$, Мариана Мурджева ${ }^{3,4,5}$, Марияна Стойчева ${ }^{1,2}$ \\ ${ }^{1}$ Кафедра инфекияионых болезней, паразитологии и тропической медицины, Медицинский университет - Пловдив, Пловдив, Болгария \\ ${ }^{2}$ Клиника инфекционых болезней и паразитологии, УМБАЛ „Св. Георги“, Пловдив, Болгария \\ ${ }^{3}$ Кафедра микробиологии и иммунологии, Медицинский университет - Пловдив, Пловдив, Болгария \\ ${ }^{4}$ Микробиологическая лаборатория, УМБАЛ „Св. Георги“, Пловдив, Болгария \\ ${ }^{5}$ Исследовательский институт, Медицинский университет - Пловдив, Пловдив, Болгария
}

Адрес для корреспонденции: Петър Василев, Кафедра инфекционых болезней, паразитологии и тропической медицины, Медицинский университет - Пловдив, бул. „Васил Априлов“ № 15А, Пловдив, Болгария; E-mail: pvasilev1985@gmail.com; Тел.: +359 898997091

Дата получения: 16 июня 2020 Дата приемки: 19 февраля $2021 \bullet$ Дата публикации: 31 августа 2021

Образец цитирования: Vasilev P, Ivanovska M, Lengerova G, Petrova A, Hristozova E, Murdjeva M, Stoycheva M. Coinfection of the intestinal tract with Aeromonas hydrophila, Clostridium difficile and Rotavirus - a case report. Folia Med (Plovdiv) 2021;63(4):57681. doi: 10.3897/folmed.63.e55496.

\section{Резюме}

Большинство случаев острой диареи у взрослых имеет инфекционную этиологию, вероятно, вирусную и самоорганизованную. Однако среди пациентов с острой диареей в большинстве случаев виноваты бактериальные агенты. В дополнение к стандартным фекальным культурам для повышения положительных результатов можно немедленно провести новый мультиплексный молекулярный тест. Авторы представляют пациента с рецидивирующей диареей, установленного с использованием культуры Aeromonas hydrophila, Rotavirus и Clostridioides difficile с помощью мультиплексного молекулярного анализа. Они обсуждают и доказывают, какой из возбудителей является наиболее вероятным и приемлемым. Плодотворное сотрудничество между врачами и интерпретация многих положительных результатов в контексте клинической картины и используемого теста были важны для лучшего лечения и хорошего результата для пациента.

\section{Ключевые слова}

Aeromonas hydrophila, Clostridium difficile, мультиплексная ПЦР 